\title{
Uncobasidium roseocremeum sp. nov. and other corticioid basidiomycetes from the Patagonian Andes of Argentina
}

\author{
Sergio P. Gorjón* Alina G. Greslebin \& Mario Rajchenberg \\ Centro de Investigación y Extensión Forestal Andino Patagónico (CIEFAP) Área de Protección, \\ CC 14, 9200 Esquel, Chubut, Argentina \\ *CORRESPONDENCE TO: spgorjon@hotmail.com
}

Abstract-Eighteen corticioid species are reported as new from the Patagonian Andes of Argentina, most of them new records for South America or for the southern hemisphere. Comments are included for all species with illustrations provided for some. Uncobasidium roseocremeum is described as new and a key to the accepted Uncobasidium species is included.

KeY wORDS-Cerocorticium, Corticiaceae, Globulicium, Globuliciopsis, wood-inhabiting fungi

\section{Introduction}

During an extensive investigation of the diversity of Corticiaceae s.l. in the Patagonian Andes forests some years ago, a total of 168 species were reported for the area (see Greslebin \& Rajchenberg 2003 for a compendium). Study of corticioid fungi in southern Argentina and Chile was recently continued (Gorjón et al. 2011a,b,c, 2012; Gorjón \& Hallenberg 2012). As a result of herbarium revisions and collections of new underexplored areas and substrata, we report here 19 noteworthy species, one of them new to science. All species represent new records for Patagonia, while some that are poorly known or show a restricted distribution are reported here for the first time for South America or the southern hemisphere.

\section{Material \& methods}

For light microscopic studies, samples were mounted in $3 \%$ potassium hydroxide $(\mathrm{KOH})$, Melzer's reagent (IKI), and $0.1 \%$ cotton blue in $60 \%$ lactic acid to determine cyanophily of basidiospores. Line drawings were made with a camera lucida attachment. All specimens here reported are deposited in the herbarium of the "Centro de Investigación y Extensión Forestal Andino Patagónico" (CIEFAP, Esquel, Argentina). Types of Uncobasidium roseocremeum are deposited in BAFC, SALA, and CIEFAP. 


\section{Recorded species}

Amaurodon viridis (Alb. \& Schwein.) J. Schröt., Pilze Schles. 1: 461, 1888.

According to Hjortstam \& Ryvarden (2007) Amaurodon viridis has a pantropical distribution. The Patagonian specimen fits the morphological species concept well.

Specimen examined-ARGENTINA. Neuquén: Lanín National Park, around Lolog lake, on dead wood of Nothofagus obliqua (Nothofagaceae), 19.V.2010, coll. S.P. Gorjón 2847.

DESCRIPTION \& ILLUSTRATION-Kõljalg (1996).

Botryobasidium isabellinum (Fr.) D.P. Rogers, Univ. Iowa Stud. Nat. Hist. 17: 11, 1935.

A cosmopolitan and widely distributed species. We have no knowledge of previous records from Argentina. In South America it is present in Brazil, Colombia, Ecuador, Guyana, Venezuela (Hjortstam \& Ryvarden 2007), and Uruguay (Martínez \& Nakasone 2010).

Specimens examined-ARGENTINA. Chubut: Los Alerces National Park, around Rivadavia lake, on dead wood of Nothofagus dombeyi, 30.III.2011, coll. S.P. Gorjón 3065, 3066; Lago Puelo National Park, Los Hitos, on dead wood of N. dombeyi, 14.V.2010, coll. S.P. Gorjón 2785. NeUQuén: Nahuel Huapi National Park, Victoria Island, on dead wood N. dombeyi, 10.XII.2009, coll. S.P. Gorjón 2561.

Description \& ILLUSTRATION-G. Langer (1994).

Cristinia eichleri (Bres.) Nakasone, Cryptog., Mycol. 29: 256, 2008.

This species differs from other Cristinia Parmasto species mainly by its odontioid to hydnoid hymenophore. It has been treated under several names in the literature [vid. Cristinia gallica (Pilát) Jülich, Cristinia mucida (Bourdot \& Galzin) J. Erikss. \& Ryvarden]. Cristinia eichleri was previously not known from the southern hemisphere (cf. Hjortstam \& Ryvarden 2007).

Specimen examined-ARgentina. Chubut: Lago Puelo National Park, Los Calabozos, on dead wood of Austrocedrus chilensis (Cupressaceae), 4.V.1998, coll. A. Greslebin 1616.

DESCRIPTION-Nakasone (2008).

Dentipellis aff. parmastoi (Nikol.) Stalpers, Stud. Mycol. 40: 37, 1996.

The examined specimen is morphologically similar to Dentipellis parmastoi, but differs in slightly narrower basidiospores, $4-5(-6) \times 2-2.2(-2.5) \mu \mathrm{m}[(4-)$ 4.5-5.5(-6) $\times(2.5-) 3-4 \mu \mathrm{m}$ in D. parmastoi]. Stalpers (1996) did not confirm the presence of cylindrical septate cystidia reported by Nikolajeva (1967), but these structures are easily distinguished in the Argentinean specimens. Dentipellis parmastoi is known only from the type locality in Russia, and in the absence of more diagnostic characters we prefer to keep the studied specimens as a morphological 'species affinis.' Hjortstam \& Ryvarden (2007) report two 
more Dentipellis species from South America: D. dissita (Berk. \& Cooke) Maas Geest., and D. leptodon (Mont.) Maas Geest., both with broader basidiospores. Specimens examined-ARGENTINA. Chubut: Los Alerces National Park, southern arm of Menéndez lake, on bark of dead Fitzroya cupressoides (Cupressaceae), 8.V.1998, coll. A. Greslebin 1628, (previously published as Hypochniciellum oblongisporum, see Greslebin \& Rajchenberg 1999). Los Alerces National Park, Alerzal milenario, on bark of dead F. cupressoides, 3.V.2010, coll. M. Rajchenberg 12294.

Gloeocystidiellum clavuligerum (Höhn. \& Litsch.) Nakasone, Mycotaxon 14: 320, 1982.

As noted by Nakasone (1982), G. clavuligerum is close to G. porosum (Berk. \& M.A. Curtis) Donk, differing in the more ellipsoid basidiospores and gloeocystidia with apical constrictions. The Patagonian specimens agree with G. clavuligerum also in basidiospore size and shape. The species is widely distributed in North America and Europe, but we are unaware of any previous records from South America. Gloeocystidiellum porosum is more common in Patagonia and has been recorded growing on several substrates (Greslebin \& Rajchenberg 2003).

Specimen examined-ARGentinA. Chubut: Los Alerces National Park, cerro

Dedal, on dead wood of Nothofagus pumilio, 9.V.1997, coll. A. Greslebin 1041.

Hyphodermella corrugata (Fr.) J. Erikss. \& Ryvarden, Cortic. N. Eur. 4: 579, 1976.

A common and widely distributed species, previously known in South America from Brazil, Colombia, and Paraguay. Hjortstam \& Ryvarden (2007) regarded its presence in Argentina as doubtful, but we now confirm its presence in Patagonia.

Specimen examined-ARGENTINA. Río Negro: Foyel, on dead wood of Nothofagus antarctica, 29.I.2010, coll. S.P. Gorjón 2595.

DEscriptions \& ILLUSTRATIONS-Eriksson \& Ryvarden (1976); Duhem (2009).

Hyphodontia breviseta (P. Karst.) J. Erikss., Symb. Bot. Upsal. 16(1): 104, 1958.

Previously reported from Colombia and northern Argentina in South America, the distribution now extends to Patagonia. It is widely distributed in the northern hemisphere.

Specimen examined-ARGENTINA. Chubut: Lago Puelo National Park, Melo river, on unidentified wood, 4.V.1998, coll. A. Greslebin 1590.

DESCRIPTION \& ILLUSTRATION-E. Langer (1994).

Jaapia ochroleuca (Bres.) Nannf. \& J. Erikss., Svensk Bot. Tidskr. 47: 184, 1953.

Plate 1

This species is recognized by the tubular thick-walled cystidia and thickwalled dextrinoid and cyanophilous basidiospores. Also known from several European countries and Kenya. 


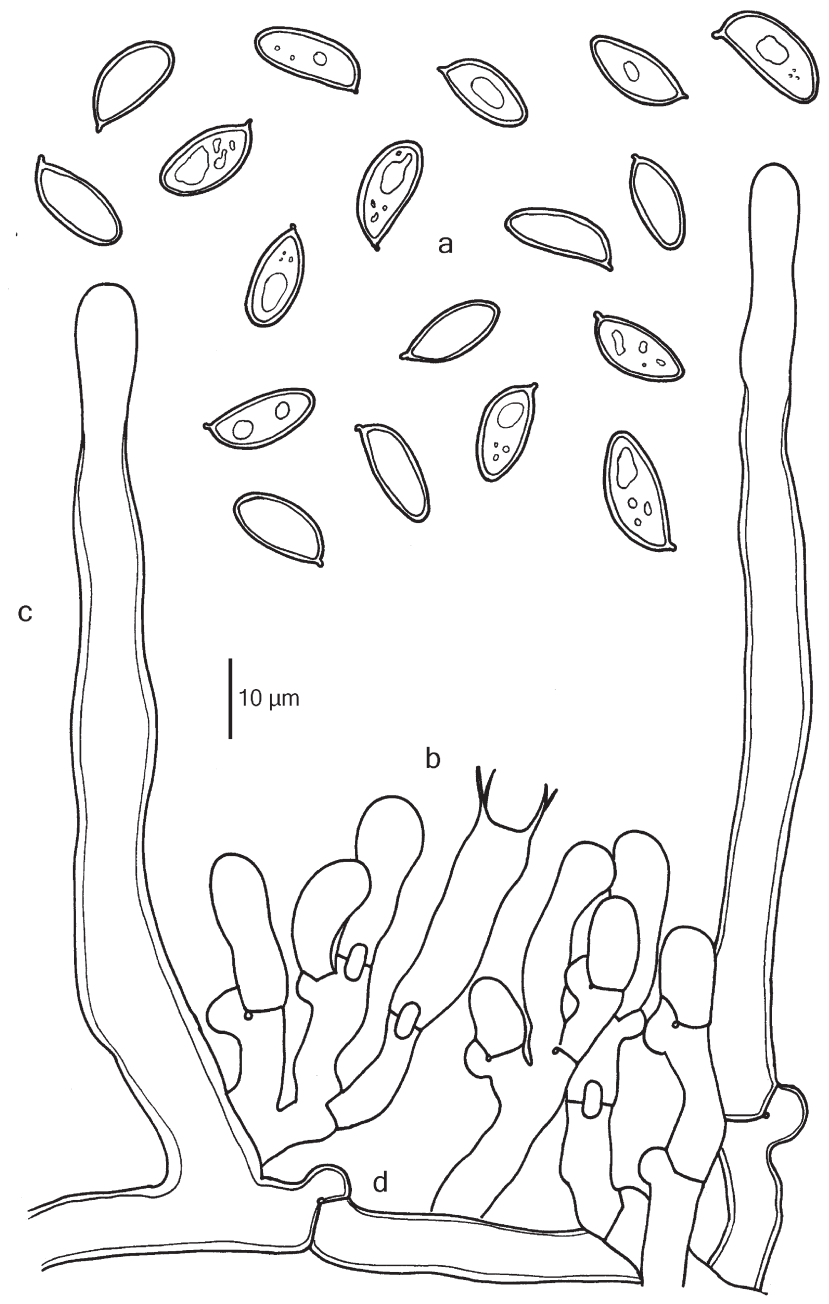

Plate 1. Jaapia ochroleuca (S.P. Gorjón 2812).

Hymenial elements: a) basidiospores; b) basidia; c) cystidia; d) hyphae.

SPECIMEN EXAmined-ARGENTINA. Neuquén: 7 lakes route, between Espejo and Correntoso lakes, on dead wood of Nothofagus dombeyi, 17.V.2010, coll. S.P. Gorjón 2812.

DESCRIPTION \& ILLUSTRATION-Eriksson \& Ryvarden (1976).

Phlebia acanthocystis Gilb. \& Nakasone, in Nakasone \& Gilbertson,

Folia Cryptog. Estonica 33: 85, 1998.

Characterized by its ventricose rostrate leptocystidia. Argentinean collections have slightly larger ellipsoid to subcylindrical basidiospores (5-6 × 


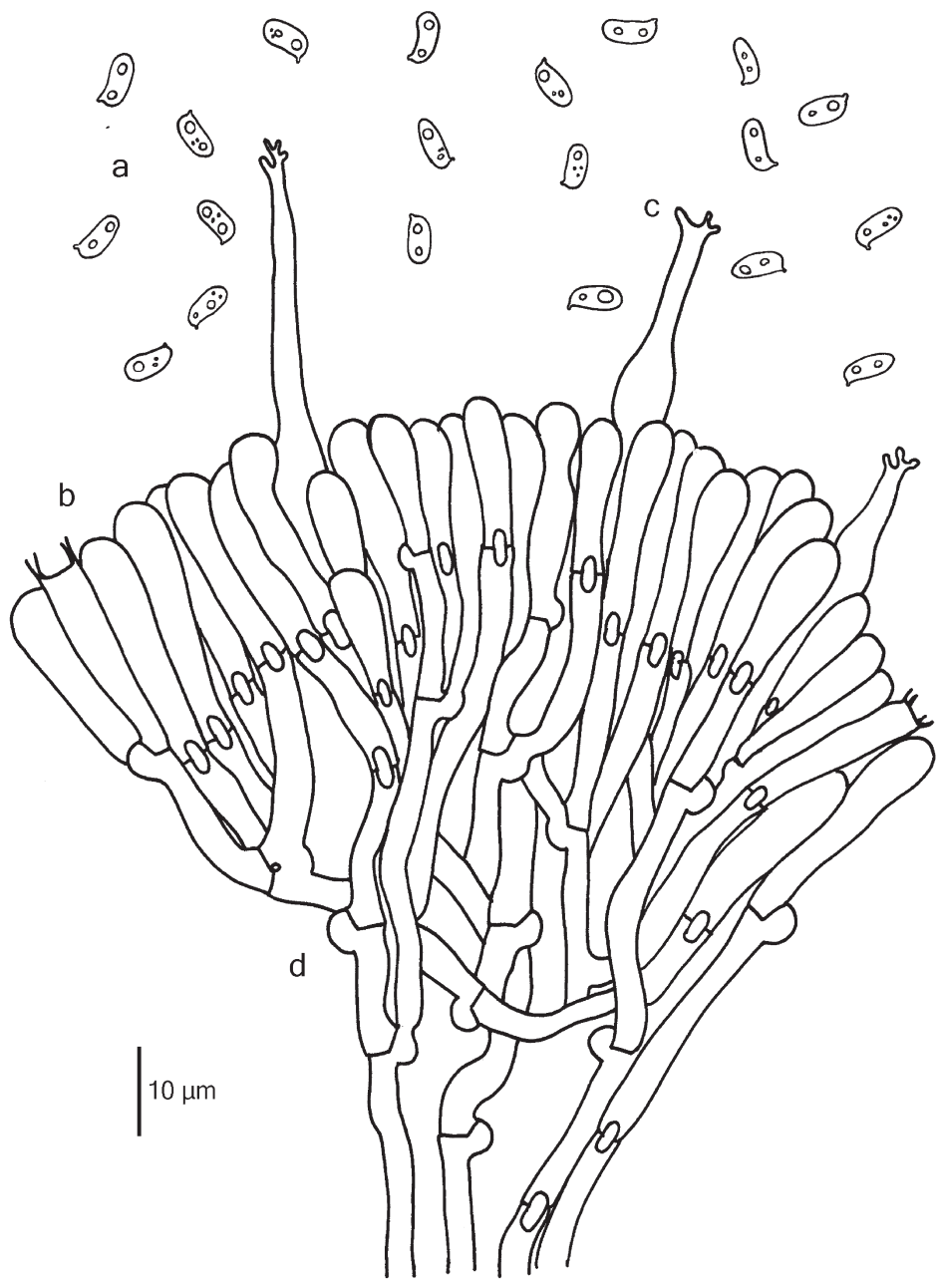

Plate 2. Phlebia acanthocystis (S.P. Gorjón 3253).

Hymenial elements: a) basidiospores; b) basidia; c) cystidia; d) hyphae.

$2-2.5 \mu \mathrm{m})$, than those reported by Nakasone \& Gilbertson (1998) [3-4.5(-5) $\times$ $(1.8-) 2-2.5 \mu \mathrm{m}]$, but other features agree well with the species concept. Duhem (2008) reported some specimens from continental France and La Réunion, with basidiospores measuring 3-4(-5) $\times 2-2.4 \mu \mathrm{m}$. Also known from the Hawaiian Islands, Japan, Réunion, and France.

SPecimens eXAmined-ARGENTINA. Chubut: Los Alerces National Park, in front of Port Chucao, on dead wood of Nothofagus dombeyi, 25.IV.2009, coll. A. Greslebin s/n. 
NeuQuéN: Nahuel Huapi National Park, Puerto Blest, on bark of dead branches of $N$. dombeyi, 15.IV.2011, coll. S.P. Gorjón 3253.

Phlebia aurea (Fr.) Nakasone, Sydowia 49: 55, 1997.

Plate 3

Among the hydnoid Phlebia Fr. species, P. aurea is diagnosed by the absence of hymenial cystidial elements and small basidiospores. Widely distributed through the temperate northern hemisphere, also known from Canary Islands, Kenya, Tanzania, and India. Also reported from southern Brazil by Gerlach \& Loguercio-Leite (2011, sub Mycoacia Donk).

Specimen examined-ARGentinA. Neuquén: San Martín de los Andes, around Lolog lake, on dead wood of Nothofagus obliqua, 19.V.2010, coll. S.P. Gorjón 2850.

DESCRIPTION \& ILLUSTRATION-Nakasone (1997).

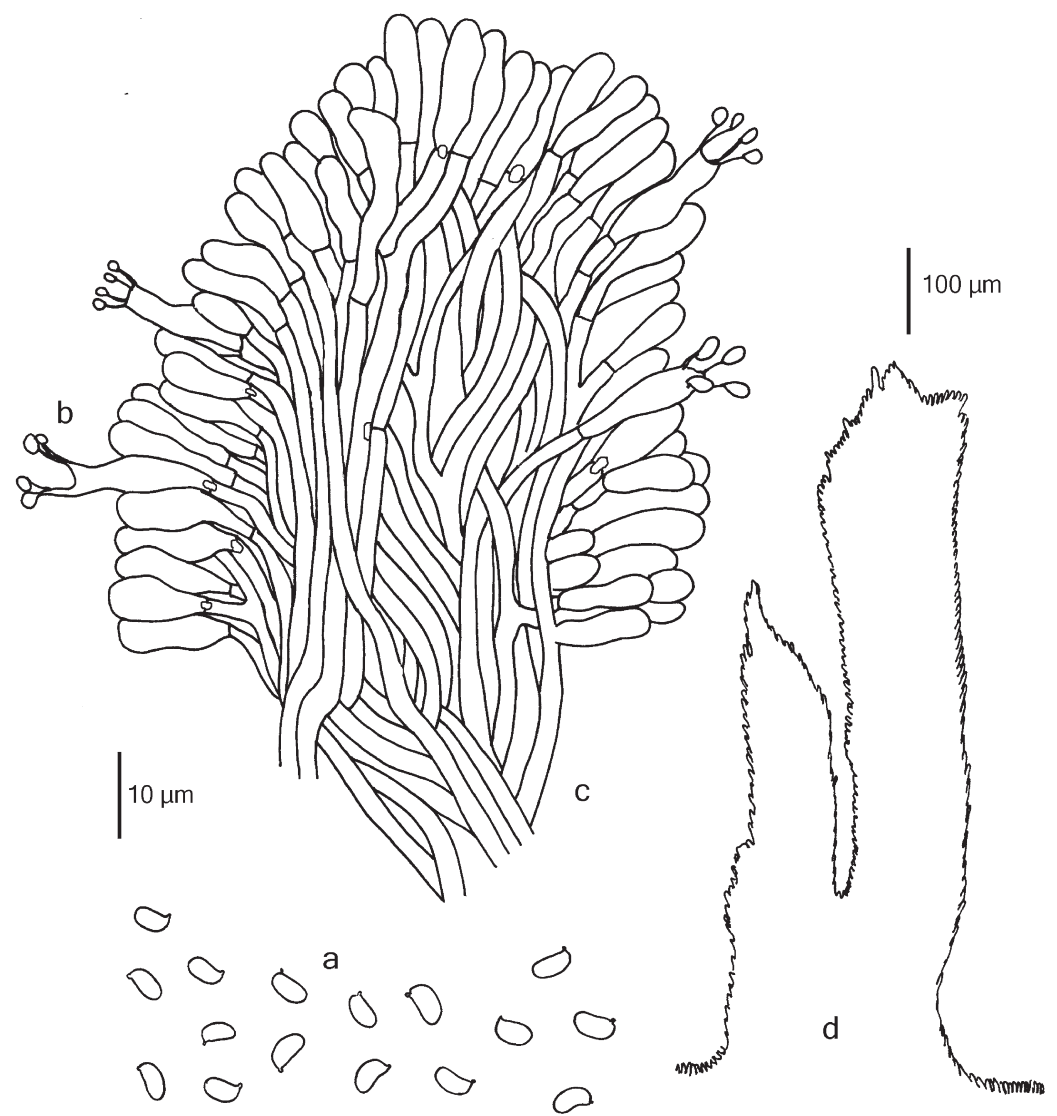

Plate 3. Phlebia aurea (S.P. Gorjón 2850).

Hymenial elements: a) basidiospores; b) basidia; c) hyphae; d) aculei section. 


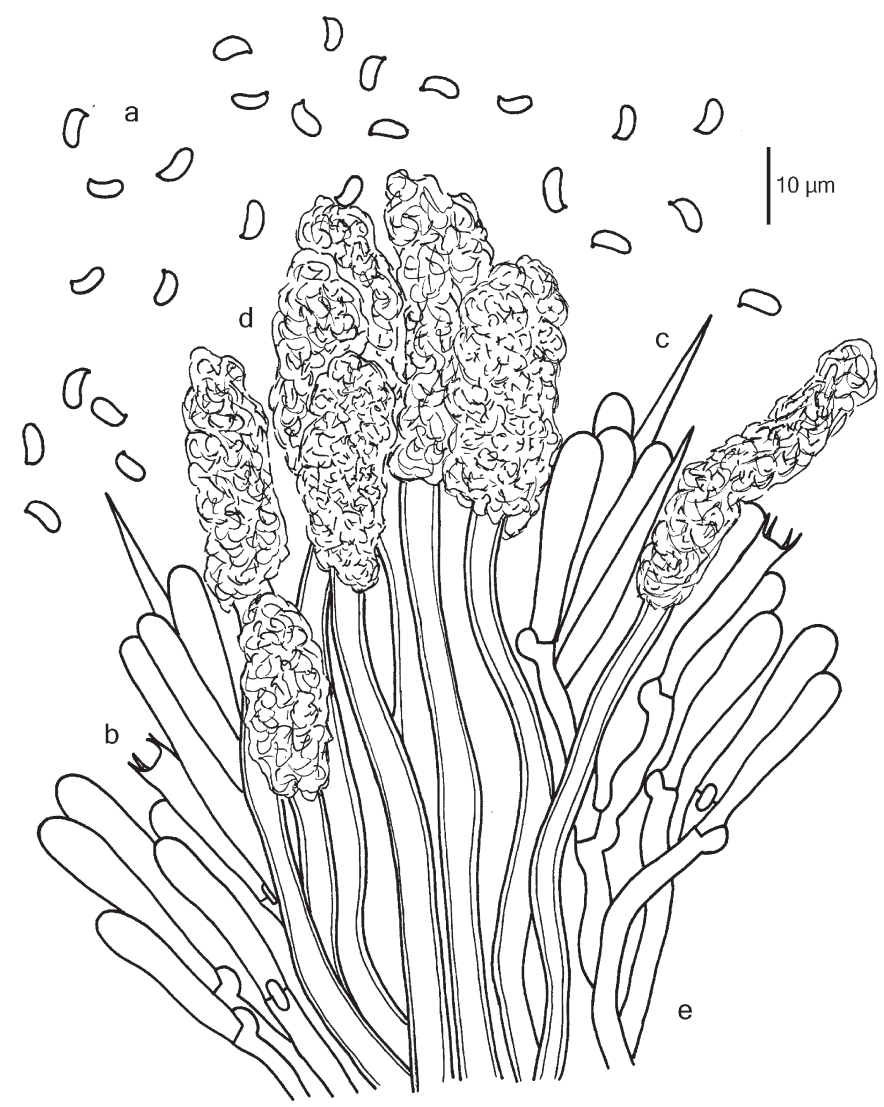

Plate 4. Phlebia subfascicularis (A. Greslebin 1644).

Hymenial elements: a) basidiospores; b) basidia; c) leptocystidia; d) encrusted hyphal ends.

Phlebia subfascicularis (Wakef.) Nakasone \& Gilb., Folia Cryptog.

Estonica 33: 87, 1998.

A very characteristic species easily to recognize macroscopically by the dark brown basidiomes with hydnoid hymenophore. Microscopically it is distinguished by the presence of subulate leptocystidia and encrusted skeletoid hyphal ends, either single or (usually) forming encrusted fascicles. Also known from Australia, Ecuador, Hawaii, and New Zealand.

Specimens examined-ARGENTINA. Chubut: Los Alerces National Park, southern arm of Menéndez lake, on dead wood of Nothofagus dombeyi, 8.V.1998, coll. A. Greslebin 1644, det. K. Nakasone; Bahía rosales stream, on dead wood of N. dombeyi, 6.V.2010, coll. S.P. Gorjón 2750. NEW ZEALAND. Westrand: Ahaura, Orwell Creek, on Nothofagus fusca, V.1955, leg. J.M. Dingley, det. G.H. Cunningham (PDD 18088). 
Phlebiopsis ravenelii (Cooke) Hjortstam, Windahlia 17: 58, 1987.

A cosmopolitan widespread species, also known from northern Argentina, Brazil, and Colombia (Hjortstam \& Ryvarden 2007) in the Neotropics.

Specimen examined-ARgentinA. Tierra Del fuego: Estancia Moat, on dead wood of Drimys winteri (Winteraceae), 12.XI.1999, coll. A. Greslebin 2185.

DESCRIPTION \& ILLUSTRATION-Bernicchia \& Gorjón (2010).

Piloderma byssinum (P. Karst.) Jülich, Ber. Deutsch. Bot. Ges. 81: 418, 1969. Plate 5

Easily identified by the yellowish, subpellicular basidiome with white rhizomorphs, simple-septate generative hyphae, and small thick-walled

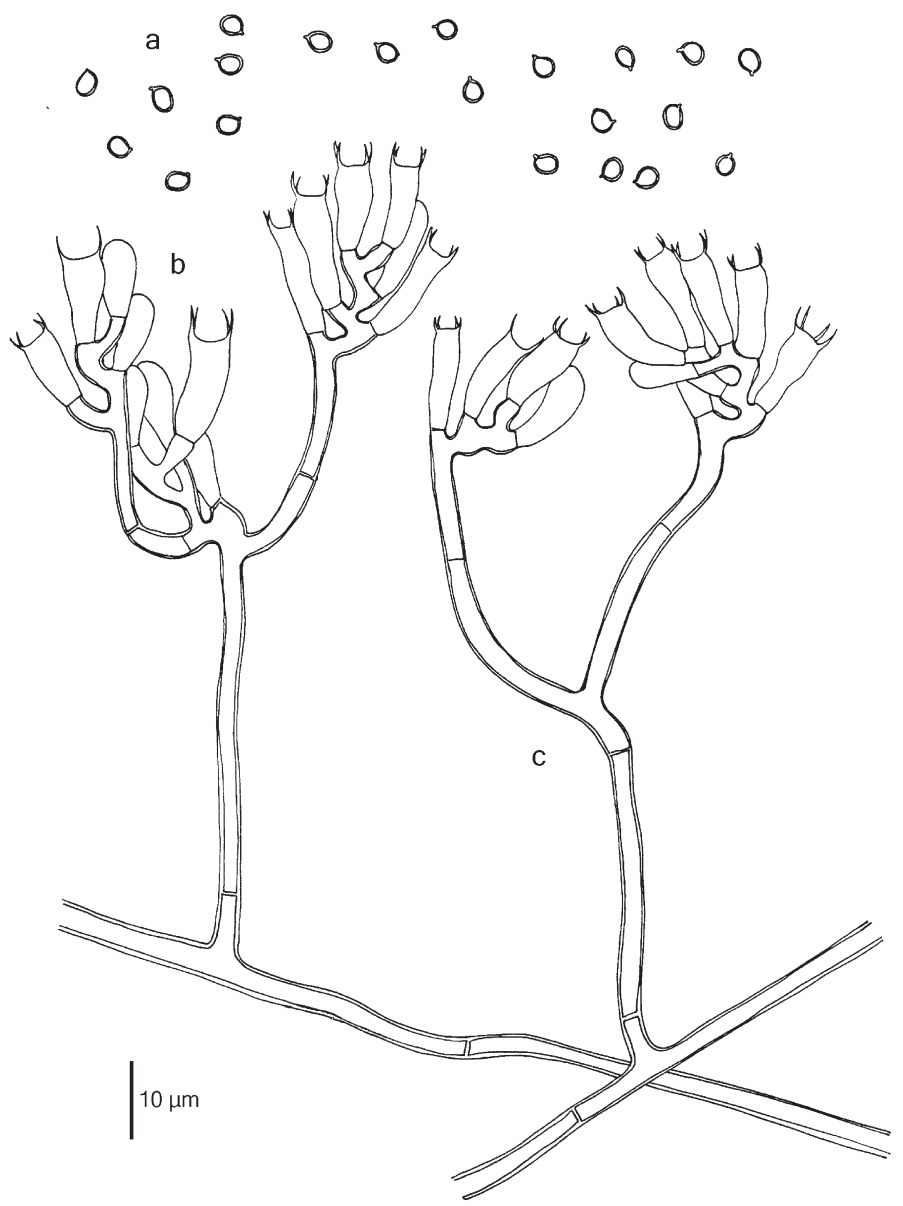

Plate 5. Piloderma byssinum (coll. M. Rajchenberg 11711). Hymenial elements: a) basidiospores; b) basidia; c) hyphae. 
basidiospores. Known from North America and Europe. New to the southern hemisphere.

SPECIMENS EXAmined-ARGENTINA. NeuQuén: San Martín de los Andes. Los Lagos, Laguna Rosales, lote 43 CORFONE, on dead wood of Nothofagus pumilio, 16.X.1998, coll. M. Rajchenberg 11711, 11714.

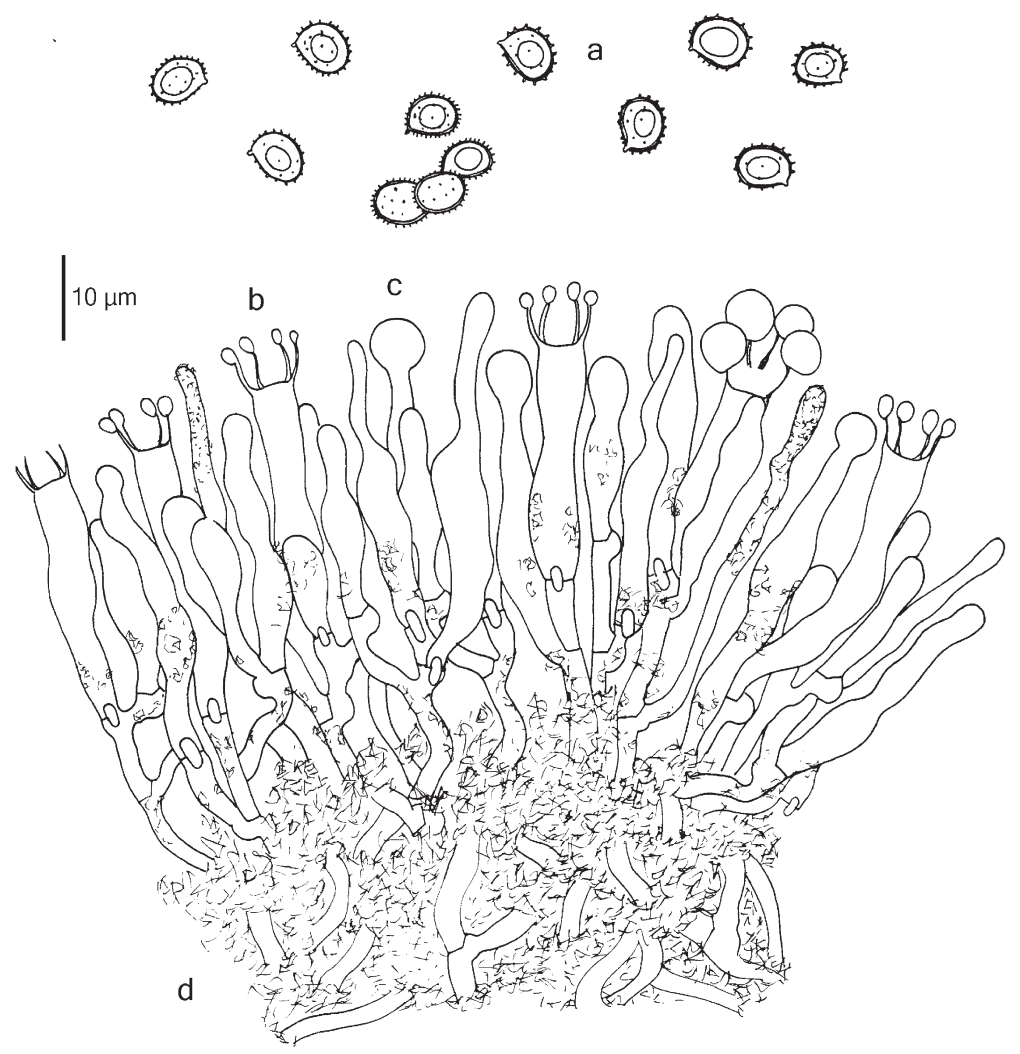

Plate 6. Rogersella griselineae (S.P. Gorjón 2701).

Hymenial elements: a) basidiospores; b) basidia; c) cystidioles; d) hyphae.

Rogersella griseliniae (G. Cunn.) Stalpers, New Zealand J. Bot. 23: 305, 1985. Plate 6 Easily identified by the globose and ornamented basidiospores and typically hyphodontoid hyphae. Known from Canary Islands, Colombia, New Zealand, Réunion, Tanzania, Vanuatu, and Venezuela.

Specimens examined-ARGENTINA. Chubut: Los Alerces National Park, southern arm of Menéndez lake, on dead wood of Nothofagus dombeyi, 3.V.2010, coll. S.P. Gorjón 2701. Neuquén: Nahuel Huapi National Park, Puerto Blest, on dead wood of $N$. dombeyi, 30.V.2010, coll. S.P. Gorjón 2957.

DESCRIPTION \& ILLUSTRATION-E. Langer (1994). 
Sistotrema subtrigonospermum D.P. Rogers, Univ. Iowa Stud. Nat. Hist. 17: 22, 1935. An inconspicuous species, but apparently widely distributed. In South America previously known from Brazil, Colombia, and Venezuela.

Specimen eXamined-ARGENTINA. Chubut: Los Alerces National Park, Arrayanes sect., on dead wood of Nothofagus dombeyi, 30.III.2011, coll. S.P. Gorjón 3054.

DESCRIPTION \& ILLUSTRATION-Gorjón \& Hallenberg (2008).

Steccherinum ochraceum (Pers.) Gray, Nat. Arr. Brit. Pl. 1: 651, 1821.

Although S. ochraceum appears widespread, we do not know previous records from Patagonia.

SPECIMEN EXAMINED-ARGENTINA. Río NEGRo: Manso inferior river, on unidentified dead wood, 10.IV.2000, coll. A. Greslebin s/n.

DESCRIPTION \& ILLUSTRATION-Bernicchia \& Gorjón (2010).

Tubulicrinis borealis J. Erikss., Symb. Bot. Upsal. 16(1): 79, 1958.

Widespread in the northern hemisphere and in South America one previous record from Uruguay (as Tubulicrinis aff. borealis) (cf. Hjortstam \& Ryvarden 2007 and Martínez \& Nakasone 2010).

Specimen examined-ARgentinA. Chubut: Los Alerces National Park, around Rivadavia lake, on dead wood of Nothofagus dombeyi, 30.III.2011, coll. S.P. Gorjón 3081.

DESCRIPTION \& ILLUSTRATION-Hjortstam et al. (1988).

Tubulicrinis confusus K.H. Larss. \& Hjortstam, in Hjortstam \& Larsson, Mycotaxon 26: 437, 1986.

Known from Europe, the Caucasus, Taiwan, and Canada. The specimen from Patagonia fits well the morphological concept.

Specimen examined-ARgentinA. Chubut: Los Alerces National Park, around Rivadavia lake, on dead wood of Nothofagus dombeyi, 26.IV.2010, coll. S.P. Gorjón 2641.

DesCription \& ILLUSTRATION-Hjortstam \& Larsson (1986); Hjortstam et al. (1988).

Uncobasidium roseocremeum Gorjón, Gresl. \& Rajchenb., sp. nov. Plates 7-10 MycoBank MB 564887

Ad Uncobasidium calongei et $\mathrm{U}$. luteolum simile sed hyphidia incrustatae presentis, basidiis bisterigmatibus, et basidiosporae globosae grandioribus.

TyPE: Argentina, Neuquén: Nahuel Huapi National Park, Puerto Blest, on bark of living Saxegothaea conspicua (Podocarpaceae), 29.V.2010, coll. S.P. Gorjón 2943 (Holotype, BAFC; isotypes, SALA, CIEFAP).

ЕтумоLоgy: roseocremeum, referring to the basidiome colour.

BASIDIOMATA resupinate, orbicular at first, then confluent, effused, membranous, whitish cream with a pinkish tint, margin white, fibrillose to rhizomorphic, subiculum creamy, felty. HYPHAL SYSTEM monomitic, generative hyphae with 


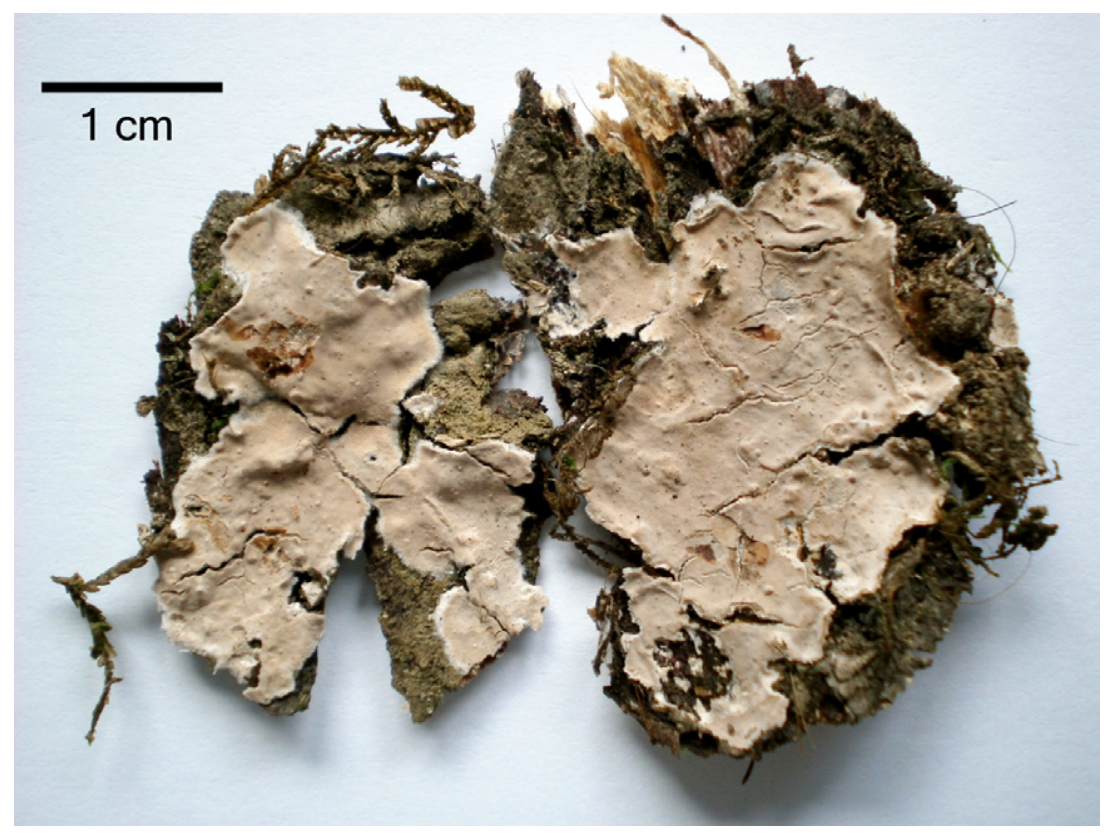

Plate 7. Uncobasidium roseocremeum (S.P. Gorjón 2824). Basidiome.

clamps, thin- to thick-walled, 3-4 $\mu \mathrm{m}$ wide, smooth or encrusted with large rounded irregular crystals, subicular hyphae yellowish, with abundant crystalline yellowish brown encrustation. CYSTIDIA absent. HYPHIDIA numerous, with an unbranched or usually branched apex, projecting above the basidial layer, some encrusted with large round crystals, in young basidiomes densely encrusted and forming a dense palisade above the immature basidia. BASIDIA narrowly clavate, sinuous, with a long stalked base, usually with one or two basal or medial lateral protuberances, thin-walled, 60-100 $\times 6-8 \mu \mathrm{m}$, guttulate, with two long sterigmata, and a basal clamp. Basidiospores globose, 11-14 $\mu \mathrm{m}$ in diam, smooth, thin or with slightly thickened walls, hyaline, guttulate, IKI-.

In Patagonia this is a quite frequent species growing exclusively on bark of Saxegothaea conspicua Lindl. (Podocarpaceae). The new species is macroscopically easily to identify by the orbicular to effuse basidiomes, whitish to cream coloured with pinkish tints. Microscopically, the large bisterigmate basidia with lateral protuberances, paraphysoid encrusted hyphae, and globose basidiospores are diagnostic.

Uncobasidium roseocremeum differs from U. luteolum Hjortstam \& Ryvarden (Hjortstam \& Ryvarden 1978) and U. calongei (Tellería) Hjortstam \& Tellería (Tellería 1985, as Cerocorticium calongei) by its larger globose basidiospores 


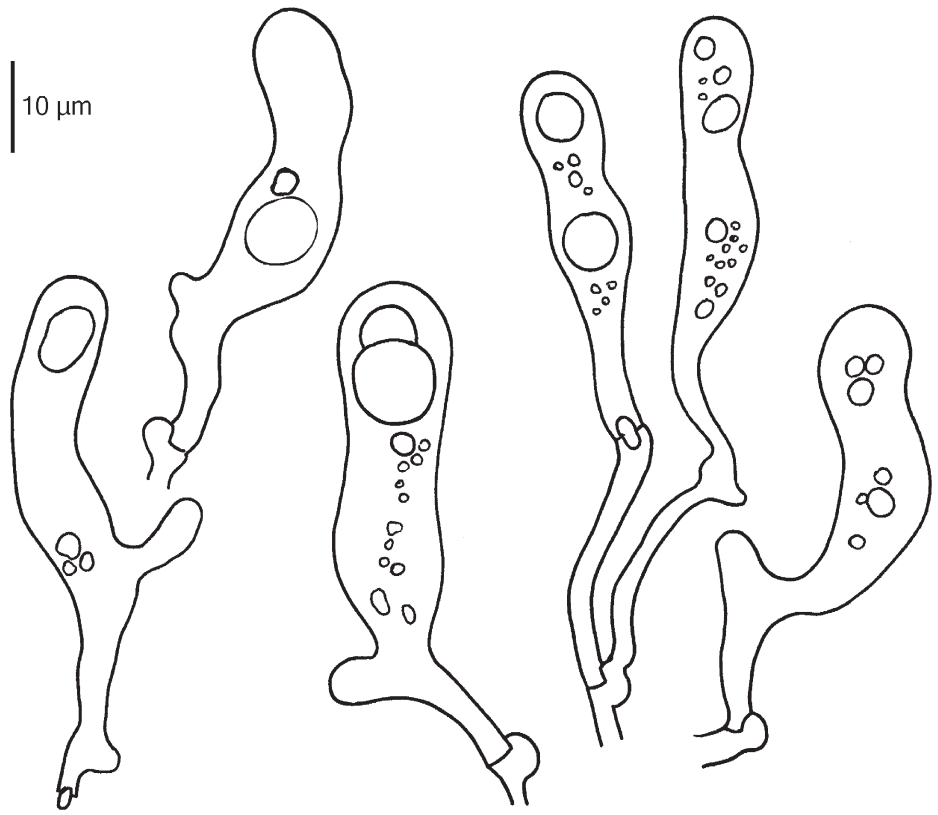

Plate 8. Uncobasidium roseocremeum (S.P. Gorjón 2943). Basidia.

and the presence of encrusted hyphidia. Furthermore, the other two Uncobasidium species occur exclusively in the northern hemisphere. Gorjón et al. (2011b) erroneously referred to the species as Globulicium hiemale (Laurila) Hjortstam. However, G. hiemale produces thinner whitish basidiomes with an undifferentiated subiculum, short and wider cylindrical basidia usually lacking or with rare lateral protuberances, and hyphidia differently encrusted with needle-like crystals. Globuliciopsis fuegiana Hjortstam \& Ryvarden, described from Tierra del Fuego, shares the presence of hyphidia and somewhat globose basidiospores but differs in the ceraceous to subgelatinous basidiomes, tuberculate and ochraceous to reddish hymenial surface, larger basidia lacking lateral protuberances, and slightly larger basidiospores more variable in shape, some oblong to broadly ellipsoid. Moreover, the three species have different host preferences.

Additional specimens examined-Globuliciopsis fuegiana. ARGENTINA. Tierra DEL FUEGo: Dpto. Ushuaia, Paso Garibaldi, on dead wood of Nothofagus betuloides, coll. A. Greslebin 1874; El Martial Mont, Ea. Moat, coll. A. Greslebin 1725, M. Rajchenberg 11282. 

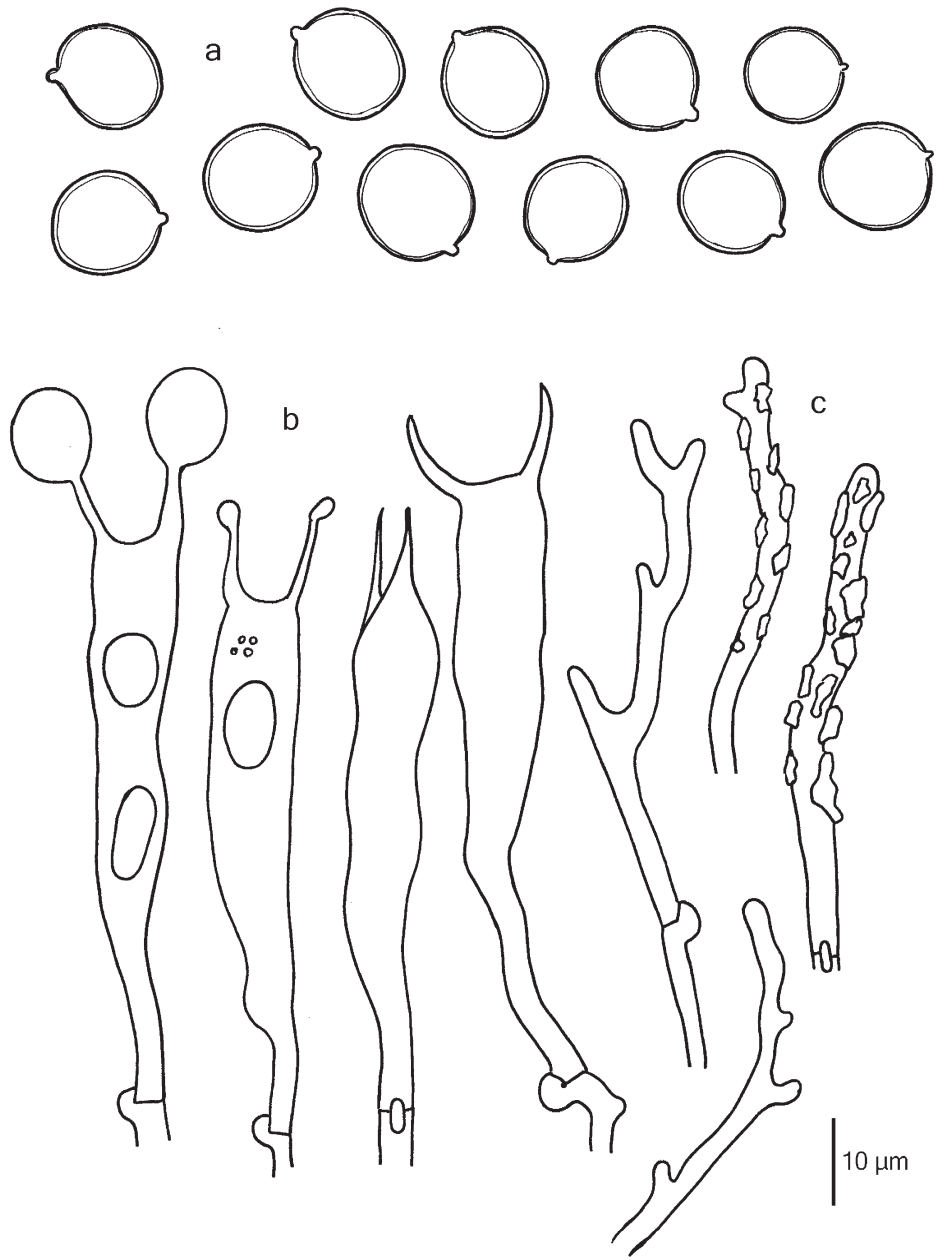

Plate 9. Uncobasidium roseocremeum (S.P. Gorjón 2943).

Hymenial elements: a) basidiospores; b) basidia; c) encrusted hyphidia.

Globulicium hiemale. NORWAY. HeDmARK: Gitvola, on dead wood of Picea abies (Pinaceae), 22.VIII.1985, coll. A. Bernicchia 3753.

Uncobasidium roseocremeum. ARGENTINA. Chubut: Los Alerces National Park, southern arm of Menéndez lake, on bark of living Saxegothaea conspicua, 3.V.2010, coll. S.P. Gorjón 2716. Río NEGRo: El Bolsón, Camping Los Alerces, on bark of living S. conspicua, 13.V.2010, coll. S.P. Gorjón 2762. NeUQUÉN: San Martín de los Andes, 


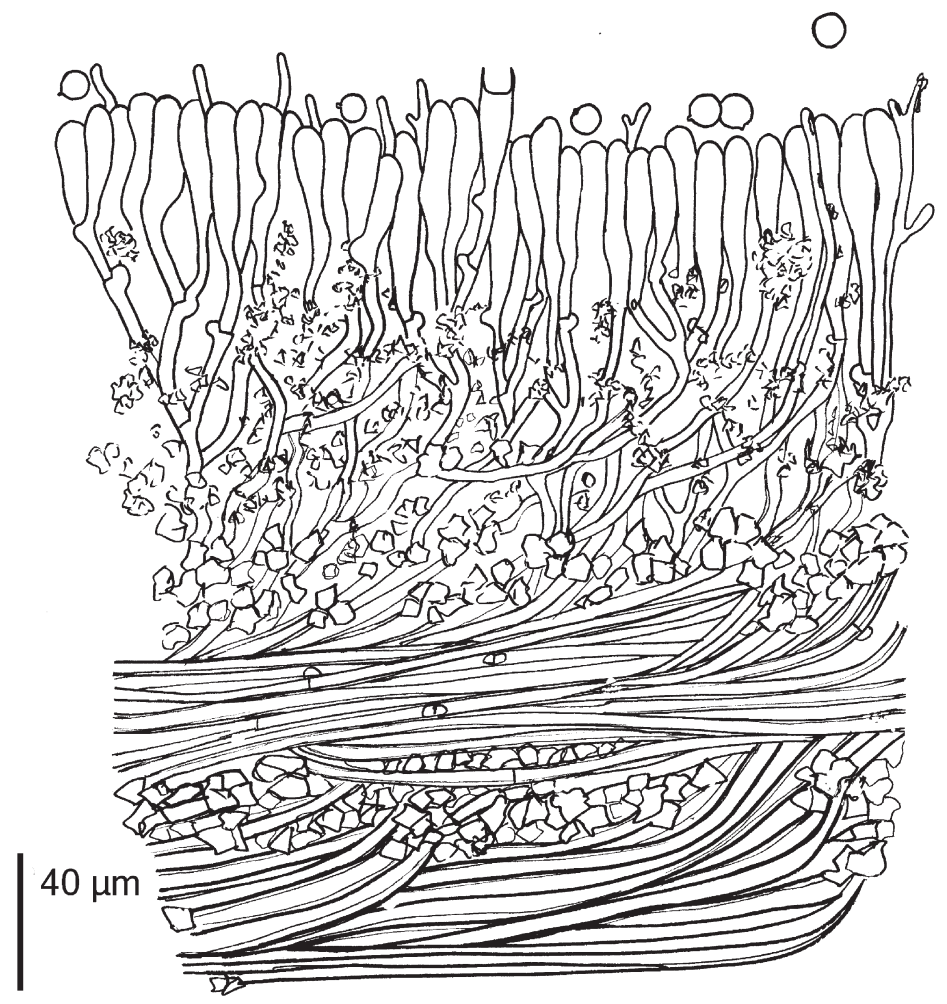

Plate 10. Uncobasidium roseocremeum (S.P. Gorjón 2943). Section of the basidiome.

Queni lake, on bark of living S. conspicua, coll. S.P. Gorjón 2824, 2827; Nahuel Huapi National Park, Puerto Blest, on bark of living S. conspicua, 29.V.2010, coll. S.P. Gorjón 2943. CHILE. X Region: Ruta 7, between El Morado bridge and Santa Lucía, on bark of living S. conspicua, 06.IV.2011, coll. S.P. Gorjón 3190.

\section{Key to the accepted Uncobasidium species}

1a. Basidiospores globose, $>10 \mu \mathrm{m}$ in diam, encrusted hyphidia present, basidia with two sterigmata.

U. roseocremeum

1b. Basidiospores ellipsoid, $\leq 10 \mu \mathrm{m}$ long, hyphidia absent,

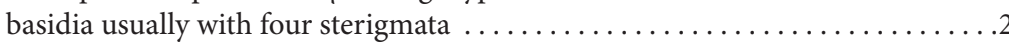

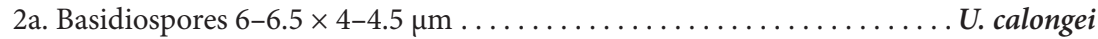

2b. Basidiospores $9 \times 6 \mu \mathrm{m} \ldots \ldots \ldots \ldots \ldots \ldots \ldots \ldots \ldots \ldots \ldots \ldots \ldots \ldots \ldots$. luteolum 


\section{Acknowledgements}

Annarosa Bernicchia (Italy) and Juliano M. Baltazar (Brazil) acted as pre-submission reviewers. Karen K. Nakasone is thanked for her identification help. The Consejo Nacional de Investigaciones Científicas y Técnicas (CONICET, Argentina) supported this research through PIP 80101000. Sergio Pérez Gorjón is a postdoctoral research fellow of the Agencia Española de Cooperación Internacional (MAEC-AECID). Alina G. Greslebin and Mario Rajchenberg are researchers of CONICET.

\section{Literature cited}

Bernicchia A, Gorjón SP. 2010. Corticiaceae s.l. Fungi Europaei. Vol. 12. Italia, Edizioni Candusso. Eriksson J, Ryvarden L. 1976. The Corticiaceae of North Europe. Vol. 4. Hyphodermella - Mycoacia. Oslo, Fungiflora.

Duhem B. 2008. À propos de plusiers Phlebia leptocystidiés: Phlebia acanthocystis, P. caspica, P. chrysocreas, P. ochraceofulva et P. subochracea - Note sur Phlebia tristis. Bull. Soc. Mycol. Fr. 124: $299-342$.

Duhem B. 2009. Le genre Hyphodermella in France. Bull. Soc. Mycol. Fr. 125: 137-168.

Gerlach A, Loguercio-Leite C. 2011. Hydnoid basidiomycetes new to Brazil. Mycotaxon 116: 183-189. http://dx.doi.org/10. $5248 / 116.183$

Gorjón SP, Hallenberg N. 2008. New records of Sistotrema species (Basidiomycota) from the Iberian Peninsula. Sydowia 60: 205-212.

Gorjón SP, Hallenberg N. 2012. Some new species and a first checklist of corticioid fungi (Basidiomycota) from Chile. Mycol. Progress (on-line first). http://dx.doi.org/10.1007/s11557-012-0824-z

Gorjón SP, Greslebin AG, Rajchenberg M. 2011a. Notes on Amylocorticiellum (Amylocorticiales, Basidiomycota), with some new combinations. Mycotaxon 116: 283-293. http://dx.doi.org/10. $5248 / 116.283$

Gorjón SP, Greslebin AG, Rajchenberg M. 2011b. Dendrothele latenavicularis sp. nov. (Agaricales, Basidiomycota) from the Patagonian Andes. Mycotaxon 117: 101-108. http://dx.doi.org/10.5248/117.101

Gorjón SP, Greslebin AG, Rajchenberg M. 2011c. Subulicystidium curvisporum sp. nov. (Hymenochaetales, Basidiomycota) from the Patagonian Andes. Mycotaxon 118: 47-52. http://dx.doi.org/10.5248/118.47

Gorjón SP, Greslebin AG, Rajchenberg M. 2012. The genus Aleurodiscus s.l. (Stereaceae, Russulales) in the Patagonian Andes. Mycol. Progress (on-line first). http://dx.doi.org/ 10.1007/s11557-012-0820-3

Greslebin AG, Rajchenberg M. 1999. Corticioid Aphyllophorales (Basidiomycota) from the Patagonian Andes Forests of Argentina 5. Some new taxa. Mycotaxon 73: 9-17.

Greslebin AG, Rajchenberg M. 2003. Diversity of Corticiaceae sens. lat. in Patagonia, Southern Argentina. New Zealand J. Bot. 41: 437-446. http://dx.doi.org/10.1080/0028825X.2003.9512861

Hjortstam K, Larsson KH. 1986. Notes on Corticiaceae (Basidiomycetes) XV. Some new species from Northern Europe. Mycotaxon 26: 437-443.

Hjortstam K, Ryvarden L. 1978. Notes on Corticiaceae (Basidiomycetes) III. Mycotaxon 7: 407-410.

Hjortstam K, Ryvarden L. 2007. Checklist of corticioid fungi (Basidiomycotina) from the tropics, subtropics and the southern hemisphere. Syn. Fung. 22: 27-146. 
Hjortstam K, Larsson KH, Ryvarden L. 1988. The Corticiaceae of North Europe 8. Phlebiella Thanatephorus - Ypsilonidium. Oslo, Fungiflora.

Kõljalg U. 1996. Tomentella and related genera in Temperate Eurasia. Syn. Fung. 9: 1-213.

Langer E. 1994. Die Gattung Hyphodontia John Eriksson. Biblioth. Mycol. 154: 1-298.

Langer G. 1994. Die Gattung Botryobasidium Donk. Biblioth. Mycol. 158: 1-459.

Martínez S, Nakasone KK. 2010. New records and checklist of corticioid Basidiomycota from Uruguay. Mycotaxon 114: 481-484. http://dx.doi.org/10.5248/114.481

Nakasone KK. 1982. Cultural and morphological studies of Gloeocystidiellum porosum and Gloeocystidium clavuligerum. Mycotaxon 14: 316-324.

Nakasone KK. 1997. Studies in Phlebia. Six species with teeth. Sydowia 49: 49-79.

Nakasone KK. 2008. Type studies of corticioids. Hymenomycetes described by Bresadola. Cryptog., Mycol. 29: 231-257.

Nakasone KK, Gilbertson RL. 1998. Three resupinate hydnaceous Basidiomycetes from Hawaii. Folia Cryptog. Estonica 33: 85-92.

Nikolajeva TL. 1967. Hydnaceae regionum Amurensis, Chabarovskensis et Primorskensis. Novosti Sist. Nizsh. Rast. 4: 237-243.

Stalpers JA. 1996. The aphyllophoraceous fungi II. Keys to the species of Hericiales. Stud. Mycol. 40: $1-185$.

Tellería MT. 1985. De Aphyllophoralibus in Hispania provenientibus ordinati commentarii, III. Anales Jard. Bot. Madrid 42: 49-60. 